\title{
Impact of ray feeding disturbances on sandflat macrobenthos: do communities dominated by polychaetes or shellfish respond differently?
}

\author{
S. F. Thrush, R. D. Pridmore, J. E. Hewitt, V. J. Cummings \\ Water Quality Centre, Marine and Freshwater, Department of Scientific and Industrial Research, PO Box 11-115, Hamilton, \\ New Zealand
}

\begin{abstract}
Studies of the influence of small-scale disturbances on soft-bottom communities have usually been conducted on one type of community only. We utilized polychaete and bivalve dominated macrobenthic communities in 2 physically similar intertidal sandflat sites to study differences in recolonization of pits created by feeding eagle rays Myliobatis tenuicaudatus. In both communities ray pits were sampled on 6 occasions until $12 \mathrm{~d}$ after their creation. Ray pits rapidly infilled with sediment of similar grain size to that of the surrounding sandflat. Organic carbon content only became elevated in the pits in the polychaete dominated community. The intensity of ray disturbance indicated that sediment within an area of 700 to $800 \mathrm{~m}^{2}$ at either site would be turned over about every $70 \mathrm{~d}$. Rapid recolonization of pits by macrofauna occurred in both communities, although bivalves tended to recolonize more rapidly than polychaetes. An epibenthic crustacean was the only species to indicate possible preferential exploitation of pits. Rapid recolonization and sediment infilling emphasise the importance of passive transport of adults into pits. The tube-mat forming polychaete Boccardia syrtis, dominant at one site, was the only common species which did not colonize pits in the same proportion to that found in the sediment adjacent to pits. The rate of sediment turnover by rays and the rapid recolonization by macrofauna indicate that rays may tend to smooth out distribution patterns, particularly those of long-lived infauna, and play a role in maintaining dominance patterns in both polychaete and bivalve communities.
\end{abstract}

\section{INTRODUCTION}

Physical disturbance to soft-bottom habitats can play an important role in determining community structure (see reviews by Thistle 1981, Dayton 1984, Probert 1984). The influence a particular disturbance may have on a community depends on the intensity, spatial and temporal extent of the disturbance, subsequent changes to the physico-chemical characteristics of the habitat, the modes and rates of colonization and the effect of residents on colonists.

Some epibenthic predators create physical disturbances by digging holes in soft-bottom habitats, e.g. ducks (Savidge \& Taghon 1988), crabs (Thrush 1986) and rays (Van Blaricom 1982). These predators can influence community structure by removing prey species, displacing other residents, providing secondary predators with access to normally unavailable prey (e.g. those that normally live deep within the sediment) and creating new opportunities for colonization.
Changes to the sediment boundary hydrodynamics also occur, with flow across depressions typically decreasing and enhancing the deposition or residence time of material transported by current flow (Nowell \& Jumars 1984). This can result in microhabitats of relatively fine sediment (Van Blaricom 1982). High levels of detritus, rich in passively transported larvae and adults (Hannan 1981, 1984, Levin 1984), can also accumulate.

In a previous study, we demonstrated that in 6 physically similar intertidal sandflats within Manukau Harbour (New Zealand), macrobenthic communities varied from place to place in relative abundance of polychaetes and bivalves (Pridmore et al. 1990). Two sites, one polychaete dominated, the other bivalve dominated, were both disturbed by feeding eagle rays Myliobatis tenuicaudatus. The effect of these smallscale excavations on community structure is likely to be influenced by the movement of organisms from adjacent undisturbed sediment, especially in areas of turbulent current flow such as intertidal sandflats. Similar 
habitats which contain distinctly different communities, with potentially different degrees of mobility, may show different responses to such disturbances. This study assessed macrobenthic assemblages in and out of pits to identify the temporal extent of the disturbance and its importance to different types of community. We also attempted to identify disproportionately abundant populations within pits in order to distinguish species exploiting pits. Assessing the impact of feeding excavations on these communities could also provide corroborative evidence as to the potential influence of ray disturbances on spatial distribution patterns of macrobenthos, as previously hypothesized from analysis of spatial patterns (Thrush et al. 1989).

\section{METHODS}

Manukau Harbour $\left(37^{\circ} 02^{\prime} \mathrm{S}_{i} 174^{\circ} 41^{\prime} \mathrm{E}\right)$, is a large $\left(340 \mathrm{~km}^{2}\right)$ shallow inlet, adjacent to Auckland, on the west coast of the North Island of New Zealand. This study was conducted on 2 intertidal sandflats, one bivalve dominated (Site BD) and the other polychaete dominated (Site $\mathrm{PD}$ ). These sites were respectively adjacent to the sites $\mathrm{AA}$ and $\mathrm{CH}$ previously described by Thrush et al. (1989) and Pridmore et al. (1990). Both sites were situated at about mid-tide level and were composed predominantly of fine sand (>93\%). Disturbances generated by rays were the only large biogenic feature apparent at either site.

Rays disturb the sandflats by jetting water into the sediment to create elliptical cone-shaped pits. Much of the sediment jetted out of the pit forms a mound on the pit's down-current side (Gregory et al. 1979). Frequently the outline of the ray can be seen surrounding new pits. The prominent blunt snout and wing shape of the outline seen at our sites indicated that eagle rays were responsible for excavations. Stingrays Dasyastis brevicaudatus and $D$. thetidis are also found in the Manukau harbour but would have left different outlines.

Casual observations indicate that rays are most prevalent on the sandflats during summer (November to March). Observations in December 1988 indicated that about 10 new pits could be found in $9000 \mathrm{~m}^{2}$ of sandflat after one tide. Large pits (longest axis $>30$ $\mathrm{cm}$ ) remained distinguishable from surrounding sediment for at least 9 tides, whereas smaller pits tend to fill much faster and were not readily apparent after 3 tides (tides are semi-diurnal in the Manukau). It was decided to sample natural pits of known age, rather than create artificial pits. While artificial pits could have been created by digging or jetting the sediment with water, the dispersal and removal of infauna (as achieved by rays) would have been difficult if not impossible to mimic. The frequency of new large pits and the desire to work within a physically similar area (ca $800 \mathrm{~m}^{2}$ ) restricted us to sampling about 5 pits at any one time at each site.

The experiment was initiated in January 1989 by marking all pits present within defined areas at Sites BD $\left(800 \mathrm{~m}^{2}\right)$ and PD $\left(724 \mathrm{~m}^{2}\right)$. As the sampling of a pit was destructive, the same 5 pits could not be sampled to give the temporal sequence. Over 3 tides new pits (longest axis $>30 \mathrm{~cm}$ ) were marked with $3 \mathrm{~mm}$ diameter stakes placed about $10 \mathrm{~cm}$ from the pit edge. Sets of 5 pits were selected randomly for sampling $1,2,4,6,9$ and 24 tides after creation at Site BD and 1,2, 4, 6, 13 and 24 tides after creation at Site PD. Five new pits marked on the first tidal cycle at each site were measured on each sampling occasion to assess changes in the dimensions of pits with infilling. Two thin poles placed on either side of these pits were used as markers and the depth of the pit was measured with reference to these poles, rather than the potentially fluctuating sediment surface.

To assess the effect of ray disturbances on macrofaunal abundance, 2 cores $(13 \mathrm{~cm}$ diameter $\times 15 \mathrm{~cm}$ depth) were collected in each pit and 2 were collected from adjacent undisturbed sediment around the pit. As the latter samples were intended to represent macrofaunal densities before ray excavation, samples were not taken from the mound of sediment which had been ejected from the pit. Samples were positioned on opposite sides of the pit, about $30 \mathrm{~cm}$ from the edge, in areas which did not show signs of previous ray disturbance (e.g. reduced density of polychaete tubes or bivalve siphons). After collection, samples were sieved $(500 \mu \mathrm{m}$ mesh) and the residue fixed in $5 \%$ formalin and $0.1 \%$ Rose Bengal in seawater.

Measurements of sediment grain size and carbon content were made on samples of surficial sediment (top $2 \mathrm{~cm}$ ) collected in and out of pits. Sediment samples were wet-sieved then dried to calculate percentage of mud, sand and gravel. Sand and gravel fractions were further split into 0.5 phi intervals by dry sieving. This method was considered appropriate because of the low proportion of mud within these sediments. Sediment carbon content was assessed as readily oxidizable carbon by the Walkley-Black procedure (Page et al. 1982, p. 570).

All data analyses were carried out on the sums of the 2 core samples collected in or out of each pit. Differences between the number of individuals collected in and out of pits on the 7 sampling occasions at each site are presented graphically as medians and ranges. The significance of differences in abundance in and out of pits was tested with the Wilcoxon Signed Rank Test (Iman \& Conover 1984, p. 256). Statistical significance was tested at the $5 \%$ probability level. 


\section{RESULTS}

Newly formed pits rapidly infilled at both sites (Table 1) and all were level with the surrounding sediment within $4 \mathrm{~d}$ at Site BD and $7 \mathrm{~d}$ at Site PD. The reduction in pit depth with time was most likely attributable to the settling of sediment transported across the bed as

Table 1. Changes in the dimensions ( $\mathrm{cm}$ ) of ray pits measured during the course of the study. Values are means $\pm \mathrm{SD}$

\begin{tabular}{|c|c|c|c|c|}
\hline \multirow[t]{2}{*}{ Tide } & \multicolumn{2}{|c|}{ Site BD } & \multicolumn{2}{|c|}{ Site PD } \\
\hline & Depth & $\begin{array}{c}\text { Longest } \\
\text { axis }\end{array}$ & Depth & $\begin{array}{l}\text { Longest } \\
\text { axis }\end{array}$ \\
\hline 1 & $12 \pm 2$ & $95 \pm 37$ & $12 \pm 3$ & $94 \pm 26$ \\
\hline 2 & $7 \pm 3$ & $95 \pm 37$ & $9 \pm 3$ & $93 \pm 26$ \\
\hline 3 & $6 \pm 3$ & $87 \pm 32$ & $8 \pm 2$ & $89 \pm 24$ \\
\hline 5 & $4 \pm 4$ & $79 \pm 31$ & $7 \pm 2$ & $83 \pm 22$ \\
\hline 8 & \multicolumn{2}{|c|}{ Not visible } & $2 \pm 2$ & $75 \pm 22$ \\
\hline 14 & & & \multicolumn{2}{|c|}{ Not visible } \\
\hline
\end{tabular}

the width of the pits remained constant over time and slumping of the pit walls was not observed.

Grain size characteristics in and out of pits at both sites were similar and did not change markedly during the course of the experiment (Table 2). Median grain size at both sites was about 2.5 phi which is characteristic of fine sands. Readily oxidizable carbon was higher at Site PD than at Site BD. Measurements of readily oxidizable carbon in and out of pits at Site BD remained close to the detection limits of the method, suggesting there was no accumulation of organic carbon in pits over time. At Site PD, however, readily oxidizable carbon appeared to accumulate in pits after 4 tidal cycles, coinciding with increased rates of infilling.

Over the initial $3 \mathrm{~d}$ of the experiment about 21 new pits (longest axis $>30 \mathrm{~cm}$ ) were recorded each day at each site. Using average pit dimensions of $12 \mathrm{~cm}$ depth and $80 \mathrm{~cm}$ diameter, about $1.4 \%$ of the area of each site is disturbed each day by the creation of large pits. At this intensity of disturbance an area equivalent to that of each site would be turned over every $70 \mathrm{~d}$. Further disruption to infaunal activities may result from the sediment ejected by rays being deposited adjacent to the pit, possibly modifying current flows and smothering infauna.

The dominance of bivalves at Site BD and polychaetes at Site PD, noted in our previous survey (Pridmore et al. 1990), was maintained during this study, as were the composition and number of species observed. The bivalve Tellina liliana was consistently the most dominant species both in and out of pits at Site BD (Fig. 1). The polychaetes Aonides oxycephala, Aquilaspio aucklandica and the amphipod Paracalliope novizealandiae were the only non-bivalve species represented in the dominance hierarchy plots of this site. The tube-mat forming spionid polychaete Boccardia syrtis maintained dominance throughout the study at Site PD (Fig. 2) with the polychaete Heteromastus filiformis always the second most dominant species. $T$. liliana was the only bivalve represented in the dominance hierarchy plots at site $\mathrm{PD}$, where the population was composed mostly of juvenile shellfish $1<6 \mathrm{~mm}$ wide). The distribution of individuals amongst the 5 most abundant species was more equitable at Site BD and no consistent difference between in and out pits was apparent. At Site PD, the distribution of individuals

Table 2. Sediment grain size characteristics, and readily oxidizable carbon (ROC) concentrations, based on an aggregate of 5 samples collected in or out of pits during the course of the experiment. " Missing values

\begin{tabular}{|c|c|c|c|c|c|c|c|c|c|c|c|c|}
\hline \multirow[t]{2}{*}{ Tide } & \multicolumn{6}{|c|}{ In pit } & \multicolumn{6}{|c|}{ Out of pit } \\
\hline & $\begin{array}{l}\text { Median } \\
\text { phi }\end{array}$ & $\begin{array}{l}\text { Graphic } \\
\text { SD }\end{array}$ & $\begin{array}{c}\% \\
\text { Gravel }\end{array}$ & $\begin{array}{c}\% \\
\text { Sand }\end{array}$ & $\begin{array}{c}\% \\
\text { Mud }\end{array}$ & $\begin{array}{c}\text { ROC } \\
\% \text { dry wt }\end{array}$ & $\begin{array}{c}\text { Median } \\
\text { phi }\end{array}$ & $\begin{array}{l}\text { Graphic } \\
\text { SD }\end{array}$ & $\begin{array}{c}\% \\
\text { Gravel }\end{array}$ & $\begin{array}{c}\% \\
\text { Sand }\end{array}$ & $\begin{array}{l}\% \\
\text { Mud }\end{array}$ & $\begin{array}{l}\text { ROC } \\
\% \text { dry wt }\end{array}$ \\
\hline \multicolumn{13}{|c|}{ Site BD } \\
\hline 1 & 2.40 & 0.40 & 1.35 & 93.38 & 6.27 & 0.07 & 2.47 & 0.54 & 3.41 & 91.42 & 5.17 & 0.05 \\
\hline 2 & 2.38 & 0.51 & 2.6 & 88.13 & 9.27 & 0.10 & 2.41 & 0.40 & 2.69 & 93.30 & 6.00 & 0.06 \\
\hline 4 & 2.46 & 0.38 & 0.14 & 98.09 & 1.77 & 0.10 & 2.48 & 0.40 & 0.83 & 95.72 & 3.45 & 0.02 \\
\hline 6 & 2.58 & 0.40 & 0.31 & 92.64 & 7.00 & 0.11 & 2.56 & 0.57 & 2.51 & 91.98 & 5.51 & 0.07 \\
\hline 9 & 2.37 & 0.35 & 0.30 & 95.99 & 3.78 & 0.03 & 2.94 & 0.44 & 1.08 & 90.97 & 7.95 & 0.03 \\
\hline 24 & 2.36 & 0.33 & 0.12 & 97.36 & 2.52 & • & 2.38 & 0.36 & 1.19 & 95.39 & 3.42 & $\cdot$ \\
\hline \multicolumn{13}{|c|}{ Site PD } \\
\hline 1 & 2.56 & 0.43 & 0.48 & 88.66 & 10.86 & 0.16 & 2.74 & 0.39 & 0.03 & 89.66 & 10.31 & 0.19 \\
\hline 2 & 2.66 & 0.40 & 0.07 & 91.90 & 8.74 & 0.13 & 2.70 & 0.40 & 0.05 & 91.00 & 7.95 & 0.17 \\
\hline 4 & 2.73 & 0.42 & 0.08 & 79.58 & 20.36 & 0.52 & 2.64 & 0.43 & 0.05 & 94.17 & 5.78 & 0.18 \\
\hline 6 & 2.75 & 0.39 & 0 & 92.00 & 8.00 & 0.32 & 2.69 & 0.43 & 0.04 & 80.7 & 19.26 & 0.18 \\
\hline 13 & 2.68 & 0.42 & 0.28 & 95.21 & 4.51 & • & 2.79 & 0.37 & 0.07 & 87.96 & 11.97 & - \\
\hline 24 & 2.76 & 0.38 & 0 & 78.28 & 21.72 & $\cdot$ & 2.74 & 0.39 & 0.07 & 83.72 & 16.21 & - \\
\hline
\end{tabular}




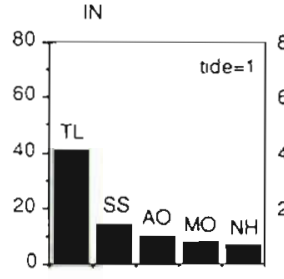

OUT
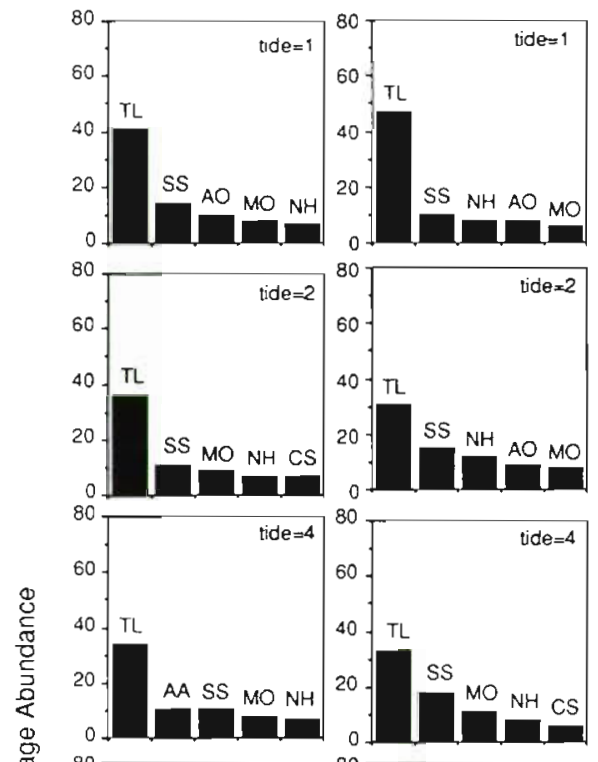

$=4$

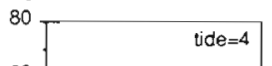

$\mathrm{NH}$
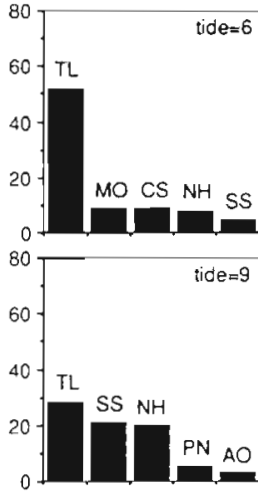

tide $=24$

Rank

Fig. 1. Dominance hierarchy plots form each sampling occasion for both in and out of pit assemblages at Site BD. TL = Tellina Llliana; $\mathrm{MO}=$ Mactra ovata $; \mathrm{CS}=$ Chione stutchburyi ${ }_{i}$ $\mathrm{NH}=$ Nucula hartvigiana; $\mathrm{SS}=$ Soletellina siliqua; $\mathrm{AO}=$ Aonides oxycephala; $\mathrm{PN}=$ Paracalliope novizealandiae AA = Aquilaspio aucklandica

amongst common species was more equitable in pits than out because $B$. syrtis accounted for about $20 \%$ less of the total number of individuals

Only 3 species were common at both sites: the cumacean Colurostylis lemurum, the polychaete Magelona ?dakini, and the bivalve Tellina liliana (Table 3 presents densities). C. lemurum was considered to be a potentially important indicator of habitat change, as pits often remain full of water during low tide and this epibenthic species may preferentially exploit the tide

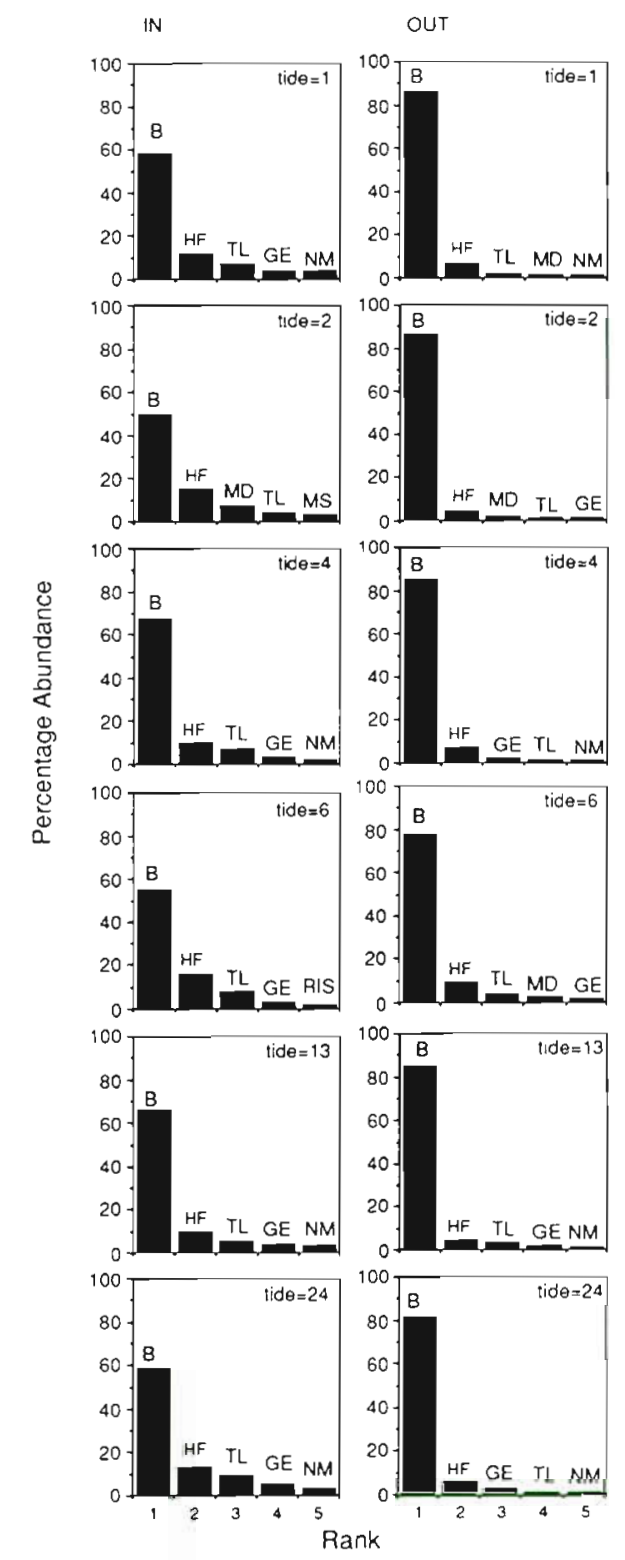

Fig. 2. Dominance hierarchy plots from each sampling occasion for both in and out of pit assemblages at Site PD. B = Boccardia syrtis; $\mathrm{HF}=$ Heteromastus filiformis $; \mathrm{GE}=$ Goniada emerita; $\mathrm{TL}=$ Tellina liliana; $\mathrm{NM}=$ Nermertinea: $\mathrm{MD}=$ Magelona ?dakini; MS = Macroclymenella stewartensis; RIS $=$ rissoid gastropod

pool condition. Some signs of exploitation were evident at Site BD where more C. lemurum were found in pits on Tides 4 and 9 . However, as the difference in density in and out of pits was always small $(<4$ individuals per core) the ecological significance of this finding is questionable. At Site PD C. lemurum were significantly more abundant in pits on the first sampling occasion only; more $C$. lemurum were found out of pits on Tide 24. The abundance of $M$. ?dakini tended to be similar in and out of pits over time at Site BD (Fig. 3), whereas at 
Table 3. Mean density (ind. core $e^{-1}$ ) over the study period, with standard error in brackets, of common species collected out of ray pits

\begin{tabular}{|c|c|c|}
\hline \multirow[t]{2}{*}{ Species } & \multicolumn{2}{|c|}{ Site } \\
\hline & $\mathrm{BD}$ & $\mathrm{PD}$ \\
\hline Magelona ?dakini & $2.3(0.4)$ & $14.8 \quad(1.1)$ \\
\hline Tellina liliana & $42.4(4.6)$ & $21.9 \quad(1.9)$ \\
\hline Colurostylis lemurum & $1.2(0.2)$ & $1.6 \quad(0.3)$ \\
\hline Aonides oxycephala & $7.2(0.9)$ & \\
\hline Nucula hartvigiana & $10.9(1.7)$ & \\
\hline Soletellina siliqua & $14.7(2.3)$ & \\
\hline Goniada emerita & & $17.4 \quad(1.5)$ \\
\hline Heteromastus filiformis & & $63.3 \quad(5.2)$ \\
\hline Boccardia syrtis & & $851.2(49.6)$ \\
\hline
\end{tabular}

Site PD this polychaete was significantly less abundant in pits on 3 of the 6 sampling occasions (Tides 1, 6 and 24). T. liliana were less abundant in pits at Site BD on Tides 1 and 2, but showed no significant difference in abundance in and out of pits at Site PD.

Differences in the density of other common species were also compared, but in no case were significantly more individuals found in pits than out. At Site BD, the dominant polychaete Aonides oxycephala exhibited higher densities out of pits on 3 occasions (Tides 2, 9 and 24) (Fig. 4). Two common bivalves at this site, Nucula hartvigiana and Soletellina siliqua, also tended to be more abundant out of pits, but this difference was

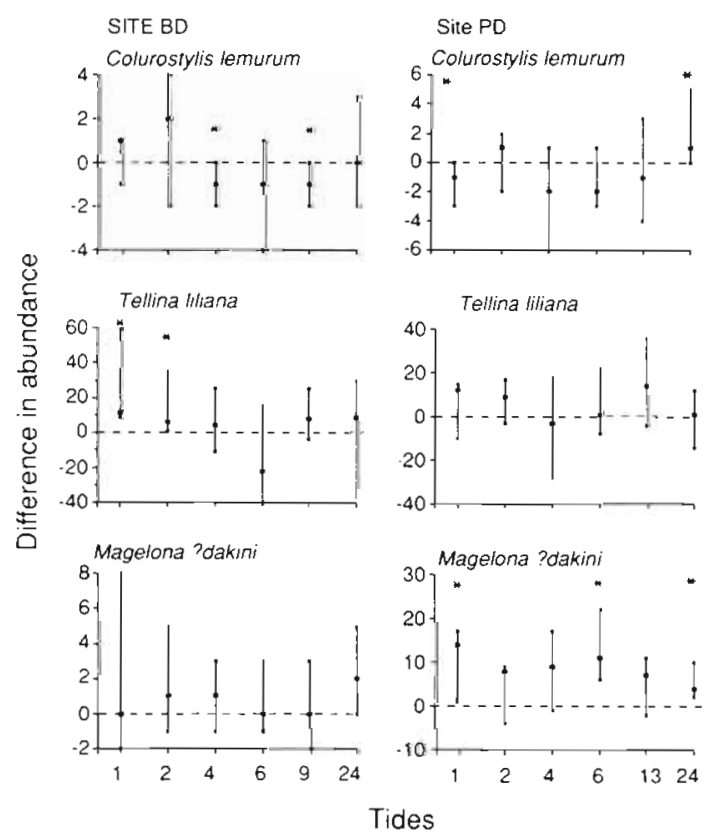

Fig. 3. Differences in abundance, based on 2 cores in and 2 cores out of pits, of common species at both Sites BD and PD. A negative difference indicates densities are higher in pits. Points represent medians, error bars the range, and ${ }^{\cdot}$ significant differences

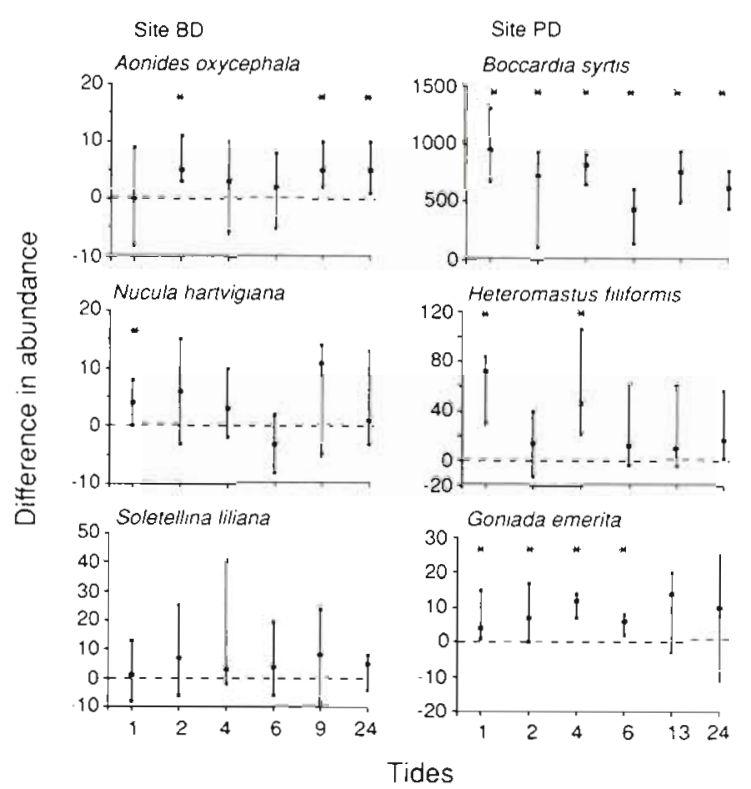

Fig. 4. Differences between in and out pit abundance of species common at either Site BD or PD. (See Fig. 3 legend)

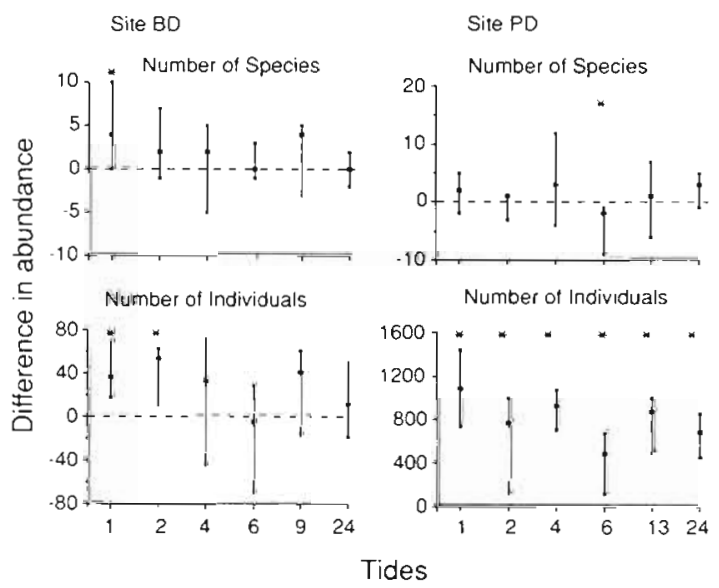

Fig. 5. Difference between in and out pit abundance of total number of taxa and individuals at Sites BD and PD. (See Fig. 3 legend)

significant only for $N$. hartvigiana on Tide 1. At Site PD, densities of the common polychaetes (Boccardia syrtis, Heteromastus filiformis and Goniada emerita) were significantly higher out of pits on most sampling occasions (Fig. 4).

Although statistical tests were performed on relatively abundant species only, visual inspection of the data indicated that some species of low to intermediate density out of pits either rarely occurred in pits (e.g. Owenia fusiformis at Site PD) or appeared to inhabit pits at lower densities (e.g. Travisia olens and Trochodota dendyi at Site BD). None colonised pits at densities higher than in the surrounding sediment. 
Differences in the total number of individuals found in and out of pits (Fig. 5) reflected differences in the densities of dominant species, in particular Tellina Liliana (at Site BD) and Boccardia syxtis (at Site PD). Significant differences in the number of taxa were only detected on 2 occasions with a higher number of taxa out of pits at Tide 1 at Site BD and a higher number of taxa in pits at Site PD after 6 tides. No species was found exclusively in or out of pits at either site.

\section{DISCUSSION}

Frequent visits to the intertidal sandflats of Manukau Harbour indicate variability in the intensity of disturbance by rays. However, the rate of disturbance observed during this study (about $1.4 \%$ of the area of each site each day) was similar to rates of disturbance by dasyatid rays obtained by Grant (1983) from the intertidal flats of South Carolina (USA) and by Reidenauer \& Thistle (1981) and Sherman et al. (1983) from shallow sublittoral sandflats in Florida (USA). Eagle ray feeding pits observed during this study rapidly filled with sediment similar in grain size to the surrounding sediment. Pits in the polychaete dominated site (PD) demonstrated elevated readily oxidizable carbon levels 4 tides after pit creation, whereas at the bivalve dominated site (BD) no change to the readily oxidizable carbon levels was apparent.

Identifying significant patterns in the differences in population density in and out of pits was limited by the experimental design and the nature of the pits studied. The 2 core samples taken from within each pit completely destroyed it, preventing further sampling. Consequently, the temporal sequence of recolonization could only be assessed as an averaged condition, complicated by potentially large variability between pits. Furthermore, pits could only be aged to within 1 tidal cycle, although they could have been created at any time the site was covered by that tide. If rapid initial changes occur in the density of organisms in pits, the variability between pits classified as being the same age increases. The rapid increase in density within pits indicates that areas carefully chosen to represent conditions immediately prior to pit formation are unlikely to be still recovering faunistically from previous disturbance. The assemblages collected from these areas are, of course, those constrained by disturbance as our observed rates of ray feeding indicate that turnover occurs in about $70 \mathrm{~d}$. Density variations within the study sites produce further differences in the recolonization of individual pits. While the pooling of the 2 individual core samples to assess differences in and out of each pit will reduce small-scale variability, variability between individual pits will still occur, reducing the power of statistical tests (Lehmann 1975). Moreover, utilizing $\alpha=0.05$ in the Wilcoxon Signed Rank test, with a sample size of 5 , it is necessary for the differences in and out of pits to be in the same direction (e.g. densities in pits always lower than densities out of pits) in each of the 5 pits. Consequently, only consistent differences could be statistically identified with our experimental design. However, the design of the experiment was constrained by logistic factors, such as the number of pits which could be sampled (obviously limited by the feeding intensity of the rays) and the need to sample all pits classified as the same age at about the same time to reduce possible temporal variation (e.g. storms).

Bivalves re-populated pits more rapidly than worms, as significant differences in bivalve density were apparent only during the first day after pit creation whereas significant differences in density were found over the $12 \mathrm{~d}$ of the study for worms. Differences in and out of pits were sustained longer in the polychaete dominated community (PD), with Boccardia syrtis still being significantly more abundant out of pits at the end of the experiment. At Site PD, B. syrtis formed a tube mat which probably reduced the rate of movement of individuals (e.g. Goniada emerita and Magelona?dakini) into pits. The other species slow to move into pits (Owenia fusiformis, Trochodota dendyi and Travisia olens) were all comparatively large vermiform animals which live below the sediment surface. Nevertheless, assemblages in and out of pits at both sites displayed a similar rank abundance structure, which is indicative of rapid colonization of pits by all species.

Previous analysis of the spatial patterns exhibited by common polychaetes and bivalves living in areas directly adjacent to the sampling sites used in this study (Thrush et al. 1989) demonstrated that all species studied were contagiously distributed with most exhibiting identifiable spatial patterns. The reasonably consistent pattern for bivalves at Site $\mathrm{BD}$ of small-scale heterogeneity within larger homogeneous density patches was suggested to result, at least partly, from disturbances generated by feeding rays The less consistent spatial patterns in the polychaete assemblage at Site PD were attributed to the potential mobility of resident infauna and the presence of runnels on the sediment surface. The results of the present study do not support the suggestion that rays influence small-scale heterogeneity because ray pits are rapidly colonized and quickly achieve macrofaunal densities similar to those found in adjacent unexcavated sediment. The only exception to this pattern was Boccardia syrtis which did not achieve similar densities in and out of pits over the duration of this study. Studies over a longer time would be needed to assess whether rays have the potential to generate 
small-scale heterogeneity in the spatial arrangement of this species. Given the ca $70 \mathrm{~d}$ turnover time, the possible influence of rays on infaunal spatial distributions across a sandflat may be better considered in terms of large-scale modifications rather than by the impact of individual pits. The mixing of sediment by rays, coupled with rapid macrofaunal colonization, may tend to smooth out distribution patterns and result in large-scale homogeneity, especially for long lived species such as bivalves.

Some previous studies of pits created by predators have emphasised animals utilizing food resources which were only abundant in pits, with numbers of individuals rapidly increasing above the densities found in the adjacent undisturbed sediment. Van Blaricom (1982) demonstrated that ray pits created in a sublittoral sand community (off La Jolla, California, USA) were rapidly colonized from the plankton by epibenthic crustaceans. When the quality/quantity of the resource in pits declined, the animals re-entered the plankton and searched for new pits to exploit.

Similarly, scavenging amphipods rapidly invaded new excavations created by grey whales (Oliver \& Slattery 1985). However, most of the significant differences observed in this study were the result of low species densities in pits, indicating that most organisms were not becoming disproportionately abundant by exploiting pit conditions. The only species which showed some sign of exploitation was the common cumacean Colurostylis lemurum. This species is also found in the demersal plankton (authors' unpubl. data) so it may behave similarly to the pit exploiting crustaceans described by Van Blaricom (1982) and Oliver \& Slattery (1985). The excavations studied by these authors showed rapid increases in crustacean density within hours or days of pit creation. Such a clear response was not observed in this study possibly because of the low densities of $C$. lemurum, the small number of pits sampled and/or the potential variability in the sequence/rate of invasion within individual pits. It is also possible that the changes brought about by the feeding rays were not significant enough to promote exploitation. At neither site did pits show distinct differences in grain size. The organic content of pits did increase over time at Site PD, but much of this could have been unavailable as a food source. On the other hand, while the crustaceans could be utilizing the ray pits as tide pools, their response to potentially higher quantity/quality of food presupposes resource limitation and this may not be relevant to habitats with shallow and enriched waters. The species could then be exploiting pits without becoming disproportionately abundant (cf. Thistle 1981).

The rapid recolonization of ray pits by most species suggests that the ability of local residents to actively move or withstand passive transport into adjacent disturbed areas is important in maintaining population densities and dominance structure. The similarity in assemblage structure in and out of pits at both sites and the lack of species which become disproportionately abundant in pits suggest that passive movement into pits, either by sediment transport or deposition from the water column, is the most important mode of recolonization. The only species with large and consistent differences in and out of pits was Boccardia syrtis (at Site PD), which formed a dense tube mat restricting transport into pits. Levin (1984) studied the rate of recolonization into pits. During the 3 yr of her study the relative abundance of species colonizing pits always reflected the species abundance in adjacent sediments, even when community structure changed in the second year as numerical dominance switched from sabellid and syllid to spionid polychaetes. Contrasting the rates of recolonization by macrofauna into plugs of azoic sand or into pits demonstrated that pits recolonized rapidly (Savidge \& Taghon 1988). In this study also, recolonization was proportional to densities in the surrounding sediment, suggesting the importance of passive advection.

The importance of passive transport into pits is obviously reduced in communities dominated by organisms which bind the sediment surface. Physical infilling of the pits in our study occurred faster in the bivalve dominated community at Site $\mathrm{BD}$ suggesting a faster rate of passive entrainment. At Site $P D$, pits filled with sediment more slowly, probably because of the dense mat of Boccardia syrtis which covered the sediment surface. However, passive entrainment still appeared to be the major mode of recolonization at Site PD, as only $B$. syrtis consistently maintained higher densities out of pits throughout the experiment. Post-larval mobility enables rapid recolonization of small-scale disturbances and thus assists in the persistence of high density populations, either of species which are dominant within the habitat (Levin 1984, Thrush 1986, Savidge \& Taghon 1988, this study) or of species which exploit pit conditions (Van Blaricom 1982, Oliver \& Slattery 1985). The response of the intertidal communities at Sites BD and PD to small-scale disturbance indicates its importance for community persistence, similar to that demonstrated in various terrestrial systems (Allen \& Starr 1982, p.104). Other factors operating on a scale greater than that of the mobility of residents (e.g. pollution, habitat change, recruitment failure or disease) need to be studied to assess the stability of this type of sandflat community.

Acknowledgements. Thanks to Drs James Blake and Geoff Read who identified the species of Boccardia. Lesley Hindmarsh assisted with field and laboratory work. The helpful comments of 2 anonymous reviewers are also appreciated. 


\section{LITERATURE CITED}

Allen, T F. H., Starr, T B. (1982). Hierarchy perspectives for ecological complexity. University of Chicago Press, Chicago

Dayton, P. K. (1984). Processes structuring some marine communities: are they general? In: Strong D. R. Jr, Simberloff, D., Abele, L. G., Thistle, A. B. (eds.) Ecological communities conceptual issues and the evidence. Princeton University Press, Princeton, p. 181-200

Grant, J. (1983). The relative magnitude of biological and physical sediment reworking in an intertidal community. $J$. mar. Res. 41: 673-689

Gregory, M. R., Ballance, P. F., Gibson, G. W., Ayling, A. M (1979). On how some rays (Elasmobranchia) excavate feeding depressions by jetting water J. sedim. Petrol. 49: $1125-1130$

Hannan, C. A. (1981). Polychaete larval settlement: correspondence of patterns in suspended jar collectors and in the adjacent natural habitat in Monterey Bay, California. Limnol. Oceanogr. 26: 159-171

Hannan, C. A. (1984). Planktonic larvae may act like passive particles in turbulent near-bottom flows. Limnol. Oceanogr 29: 1108-1116

Iman, R. L., Conover, W J. (1984). A modern approach to statistics. John Wiley \& Sons, New York

Lehmann, E. L. (1975). Nonparametrics: statistical methods based on ranks. Holden-Day Publ., San Francisco

Levir, L. A. (1984). Life history and dispersal patterns in a dense infaunal polychaete assemblage: community structure and response to disturbance. Ecology 65: 1185-1200

Noweil, A. R. M., Jumars, P. A. (1984). Flow environments and aquatic benthos. Ann. Rev. Ecol. Syst. 15: 303-328

Oliver, J. S., Slattery, P.N. (1985). Destruction and opportunity

This article was submitted to the editor on the sea floor: effects of gray whale feeding. Ecology 66: 1965-1975

Page, A. L., Miller, R. H., Keeney, D. R. (1982), Methods of soil analysis. Part 2, Chemical and microbiological properties, 2nd edn. American Society of Agronomy and Soil Science Society of America, Madison, Wisconsin

Pridmore, R. D., Thrush, S. F., Hewitt, J. E., Roper, D. S. (1990). Macrobenthic community composition of six intertidal sandflats in Manukau Harbour, New Zealand. N.Z.Jl. mar Freshwat. Res. 24: 81-96

Probert, P. K. (1984). Disturbance, sediment stability, and trophic structure of soft-bottom communities. J. mar. Res. 42: 893-921

Reidenauer, J. A., Thistle, D. (1981). Response of soft-bottom harpacticoid copepod community to a stingray (Dasyatis sabina) disturbance. Mar. Biol. 65: 261-267

Savidge, W. B., Taghon, G. L. (1988). Passive and active components of colonization following two types of disturbance on and intertidal sandflat. J. exp. mar. Biol. Ecol. 115: 137-155

Sherman, K. M., Reidenauer, J. A., Thistle, D., Meeter, D. (1983). Role of a natural disturbance in an assemblage of free-living nematodes. Mar. Ecol. Prog. Ser 11:23-30

Thistle, D. (1981). Natural physical disturbances and the communities of marine soft bottoms. Mar Ecol. Prog. Ser 6: 223-228

Thrush, S. F. (1986). Spatial heterogeneity in subtidal gravel generated by the pit-digging activity of Cancer pagurus. Mar. Ecol. Prog. Ser. 30: 221-227

Thrush, S. F., Hewitt, J. E., Pridmore, R. D. (1989). Patterns in the spatial arrangement of polychaetes and bivalves in intertidal sandflats. Mar. Biol. 102: 529-536

Van Blaricom, G. R. (1982). Experimental analysis of structural regulation in a marine sand community exposed to oceanic swell. Ecol. Monogr. 52: 283-305

Manuscript first received; July 24, 1990

Revised version accepted: October 25, 1990 